Сергій Білявець, кандидат педагогічних наук, Національна академія Державної прикордонної служби України ім. Богдана Хмельницького

\title{
ЕКСПЕРИМЕНТАЛЬНЕ ДОСЛІДЖЕННЯ РЕЗУЛЬТАТИВНОСТІ МЕТОДИЧНОЇ СИСТЕМИ ФОРМУВАННЯ ПРОФЕСІЙНОЇ КОМПЕТЕНТНОСТІ МАЙБУТНІХ ОФІЦЕРІВ-ПРИКОРДОННИКІВ У ПРОЦЕСІ НАВЧАННЯ ВІЙСЬКОВО-СПЕЦІАЛЬНИХ ДИСЦИПЛІН
}

У статті охарактеризовано основні кроки щуодо формування професійної компетентності майбутніх офіцерів-прикордонників у прочесі навчання з військовоспеціальних дисииплін. Використання методичної системи в експериментальній роботі передбачало виведення з рівноваги замкнутої системи освітнього процесу ВНЗ ДПСУ шляхом впливу на всі ї̈ підсистеми. Автор розкриває основні заходи у підсистемі мети $i$ завдань, зокрема, щзодо визначення иілей навчання офічера-прикордонника на основі діяльнісного підходу, моделі випускника ВВНЗ та результатів формування професійної компетентності майбутніх офрічерів-прикордонників. Висвітлено також заходи, щчо стосувалися підсистеми результатів формування професійної компетентності майбутніх офічерів-прикордонників, підсистеми діяльності науково-педагогічного складу ВВНЗ, підсистеми змісту навчання військово-спеціальних дисииплін та підсистеми діяльності курсанта.

Ключові слова: офіџер-прикордонник; професійна компетентність; методична система; підсистема мети і завдань; методи навчання; військово-спеиіальні дисиипліни.

Постановка проблеми. Сьогодні необхідність підвищення рівня боєздатності органів Державної прикордонної служби України (ДПСУ) та їх спроможності до виконання завдань із захисту державного кордону, відповідно до Стратегії розвитку прикордонного відомства, актуалізує потребу в підготовці висококваліфікованих офіцерських кадрів, здатних не лише приймати обгрунтовані та ефективні управлінські та професійні рішення з питань охорони державного кордону, а й планувати і проводити спеціальні операції в зоні проведення антитерористичної операції, володіти всіма видами сучасного озброєнням, військовою і спеціальною технікою, знати тактику і стратегію ведення бойових дій, особливості організованого і швидкого переміщення сил i засобів підрозділів, частин та з’єднань тощо.

Офіцер-прикордонник повинен бути професіоналом у різних видах діяльності, володіти динамічною комбінацією знань, умінь i практичних навичок, способами мислення, професійними, світоглядними і громадянськими якостями, морально-етичними цінностями, а також бути здатним успішно здійснювати професійну діяльність - мати високий рівень професійної компетентності. Однак традиційна система професійної підготовки майбутніх офіцерів не завжди забезпечує очікуваний результат.

Аналіз останніх досліджень і публікацій. Особливості професійної діяльності офіцера-прикордонника є предметом уваги досліджень О. Діденка [1], С. Мула [2], Б. Олексієнка [3], В. Осьодла [4], О. Ставицького [5], 
Є. Стасюка [6], Г. Темка [7] та О. Тімченка [7]. Однак комплексного дослідження 3 питань розроблення, обгрунтування та удосконалення методичної системи формування професійної компетентності майбутніх офіцерів-прикордонників у процесі навчання загальновійськових та військовоспеціальних дисциплін на сьогодні немає.

Метою статті $\epsilon$ висвітлення перебігу експериментального дослідження щодо перевірки результативності методичної системи формування професійної компетентності майбутніх офіцерів-прикордонників у процесі навчання військово-спеціальних дисциплін.

Виклад основного матеріалу. Педагогічний експеримент було організовано відповідно до завдань дослідження. При організації експериментальної роботи було визначено склад учасників експерименту, ознайомлено їх із завданнями експерименту. У різних видах дослідження взяли участь 236 курсантів Національної академії Державної прикордонної служби ім. Б. Хмельницького (НАДПСУ) та 44 представники науково-педагогічного складу. Формувальний етап педагогічного експерименту тривав з вересня 2013 до травня 2017 року. Його було організовано на базі чотирьох факультетів НАДПСУ.

Формувальний етап педагогічного експерименту передбачав чотири етапи відповідно до років навчання курсантів. 3 урахуванням того, що цільовий компонент $\epsilon$ основоположним вектором формування професійної компетентності майбутніх офіцерів-прикордонників у процесі навчання військово-спеціальних дисциплін, при організації експериментальної роботи було визначено цілі навчання військово-спеціальних дисциплін відповідно до вимог, викладених в освітніх документах.

Цілі також відображали предмет навчальної діяльності офіцераприкордонника, зміст навчального матеріалу, елементи навчальної діяльності курсантів та елементів процесу досягнення мети при формуванні особистісного досвіду курсантів та їх професійно значущих якостей. Наприклад, на першому курсі здійснювалась підготовка молодшого інспектора прикордонної служби молодшого прикордонного наряду. Цю підготовку забезпечували навчальні дисципліни «Тактика прикордонної служби (Основи охорони державного кордону)», «Прикордонний контроль (Служба прикордонних нарядів в пунктах пропуску через державний кордон)».

На 2-му курсі навчання було організовано підготовку інспектора прикордонної служби (старшого прикордонного наряду). Цю підготовку забезпечували навчальні дисципліни «Тактика прикордонної служби (Охорона державного кордону прикордонним підрозділом)», «Прикордонний контроль (Перевірка документів»). Додатково на 2-му курсі навчання було передбачено сформувати в курсантів навички командира механізованого взводу шляхом вивчення навчальної дисципліни «Тактика загальновійськових підрозділів».

На 3-му курсі навчання організовано підготовку начальника відділення інспекторів прикордонної служби (старшого зміни прикордонних нарядів). Цю підготовку забезпечували навчальні дисципліни «Тактика прикордонної служби 
(Управління службою прикордонного підрозділу)», «Прикордонний контроль (Здійснення прикордонного контролю)». Додатково на 3-му курсі навчання було організовано підготовку офіцера для виконання обов'язків командира роти шляхом вивчення навчальної дисципліни «Тактика загальновійськових підрозділів».

На 4-ому курсі навчання було завершено підготовку курсантів до виконання функцій начальника відділу прикордонної служби III та IV категорії. Основними дисциплінами, які забезпечували формування професійної компетентності, на цьому етапі були «Тактика прикордонної служби (управління прикордонним підрозділом)», «Прикордонний контроль (Організація прикордонного контролю»). Додатково на 4-му курсі навчання здійснено підготовку командира батальйону шляхом вивчення навчальної дисципліни «Тактика загальновійськових підрозділів».

3 використанням діяльнісного підходу цілі в навчанні було визначено 3 урахуванням необхідних результатів навчання, виражених у діях курсантів, через категорії «знати» (зміст навчального матеріалу) i «вміти» (дії, які повинен виконувати курсант у результаті освоєння цього матеріалу). У такому випадку, наприклад, мету навчання дисципліни «Тактика прикордонної служби (управління прикордонним підрозділом)» було визначено як опис видів діяльності, перелік професійних умінь, необхідних офіцерові-прикордоннику для вирішення завдань 3 охорони кордону, а також усіх тих особистісних характеристик, які слід сформувати в процесі засвоєння дисципліни.

Визначення цілей навчання військово-спеціальних дисциплін означало формування системи умінь, якими повинні оволодіти курсанти. Стратегічним цілям навчання відповідав навчальний план професійної підготовки, тактичні цілі стосувалися окремих військово-спеціальних дисциплін. У свою чергу оперативні цілі окремих тем військово-спеціальних дисциплін на першому курсі передбачали формування професійної компетентності молодшого інспектора прикордонної служби, на другому - інспектора прикордонної служби, на третьому - начальника відділення інспекторів прикордонної служби, на четвертому - начальника відділу прикордонної служби. Наприклад, було передбачено, що для формування професійної компетентності начальника відділу прикордонної служби III та IV категорії курсанти мають засвоїти порядок відпрацювання документів у системі ГАРТ-1, ГАРТ-3П «Адміністратор» щодо організації оперативно-службової діяльності відділу на місяць (АРМ Начальника відділу та його заступника з ОСД).

3'ясування цілей дало можливість належним чином визначити зміст, методи, засоби i форми навчання військово-спеціальних дисциплін, проконтролювати результати навчання офіцерів-прикордонників, що повинні відповідати вимогам нормативних документів. На основі цілей навчання далі було розроблено зміст військово-спеціальних дисциплін i технології їх освоєння.

В експериментальному дослідженні для побудови процесу викладаннянавчання саме навколо курсантів, їхніх знань, ставлення, навичок і досвіду, 
було широко використано методи навчання, орієнтовані на курсантів, методи навчання, орієнтовані на викладача, та інтерактивні методи навчання, орієнтовані на курсанта й викладача. Зокрема, серед методів навчання, орієнтованих на курсанта, важливе значення мала робота в невеликій групі, коли вони мали можливість взаємодіяти один 3 одним. Курсанти також виконували проектну роботу в невеликих групах. Наприклад, при вивченні 3 навчальної дисципліни «Тактика прикордонної служби (управління прикордонним підрозділом)» таким продуктом, що його курсанти 4-го курсу повинні були отримати в результаті проектної роботи, були рішення та рекомендації щодо взаємодії та всебічного забезпечення оперативно-службової діяльності відділу прикордонної служби. Для виконання цього завдання курсанти повинні були розміркувати над визначенням «організація ОСД» та «управління відділом», довести, на підставі чого здійснюється організація оперативно-службової діяльності відділу, терміни іiі організації; з'ясувати розглянути зміст організації оперативно-службової діяльності відділу, алгоритм роботи начальника відділу прикордонної служби щодо організації оперативнослужбової діяльності.

Загалом для формування професійної компетентності майбутніх офіцерівприкордонників у процесі навчання військово-спеціальних дисциплін при використанні різних груп методів було ураховано їх доцільність та прийнятність, переваги і недоліки. Ці методи викладачі використовували системно, варіювали залежно від обставин педагогічного процесу та специфіки професійної компетентності, оптимально пристосовуючи до закономірностей військово-спеціальних дисциплін та особливостей вікового й індивідуального розвитку курсантів.

У підсистемі результатів формування професійної компетентності майбутніх офіцерів-прикордонників викладачі звертали увагу на актуалізацію і збагачення суб'єктного досвіду курсантів, стимулювали їх до самостійного вибору i використання різних способів виконання навчальних завдань, відпрацьовували різні версії при пошуку варіантів вирішення пізнавальних завдань (проблем). Наприклад, курсанти при навчальної дисципліни «Тактика прикордонної служби (управління прикордонним підрозділом)» аналізували різні особливості роботи начальника відділення інспекторів прикордонної служби 3 управління службою зміни прикордонних нарядів, прослідковували різні варіанти його рішень при ускладненні морально-психологічного стану підрозділу, визначали шляхи та напрями покращення міжособистісної взаємодії у підрозділі, різні варіанти управлінсько-комунікативного впливу начальника відділення у повсякденних та конфліктних ситуаціях.

Така організація спільної діяльності, створення ситуацій вибору та заохочення ініціативи сприяли розвитку активності курсантів у навчальній діяльності, їх відповідальності за результати своєї праці, тобто курсанти ставали співавторами процесу власного навчання. Роль викладача за таких умов суттєво змінювалася. Викладачі намагалися не тільки повідомляти новий матеріал, але 
й бути організаторами, фасилітаторами, консультантами. Партнерство у такому випадку замінювало домінування викладача в аудиторії.

У свою чергу в підсистемі діяльності науково-педагогічного складу ВВНЗ викладачі особливу увагу звертали на створення сприятливих умов для врахування і розвитку індивідуальних якостей курсанта, його внутрішнього потенціалу, для реалізації потенційних можливостей майбутніх захисників кордону. Йдеться про організацію навчального процесу, що передбачає вибір способів, прийомів, темпу навчання курсантів, ураховує їх індивідуальні відмінності, рівень розвитку здібностей до навчання.

У підсистемі змісту навчання військово-спеціальних дисциплін при визначенні змісту навчання було враховано мету та результати навчання, зокрема ті характеристики, що їх повинен мати офіцер-прикордонник після завершення навчання. Усі військово-спеціальні дисципліни було структуровано відповідно до послідовності (основних етапів) професійної діяльності офіцераприкордонника: від молодшого прикордонного наряду, командира відділення механізованого взводу, інспектора прикордонної служби (старшого прикордонного наряду), командира механізованого взводу, начальника відділення інспекторів прикордонної служби (старшого зміни прикордонних нарядів), командира роти до начальника відділу прикордонної служби III та IV категорії, командира батальйону. Системотвірним елементом при визначенні складу і структури навчального предмета була сфера охорони державного кордону як об'єкт вивчення.

При підготовці офіцерів-прикордонників з курсу в курс зміст зазначених дисциплін циклу професійної та практичної підготовки ми суттєво розширювали у зв'язку зі зміною діапазону діяльності та розширенням об'єкта вивчення: відповідно від підготовки молодшого інспектора прикордонної служби до підготовки начальника відділу прикордонної служби III та IV категорій. Військово-спеціальні навчальні дисципліни у такому випадку розширювалися за рахунок поглиблення їх теоретичних положень, при цьому на кожному з етапів уявлення про ті чи інші елементи професійної діяльності ми поглиблювали і конкретизували.

У підсистемі діяльності курсанта важливого значення мало забезпечення моніторингу якості навчальної діяльності курсантів, звертаючи увагу на всі іiі складові, зокрема мотиваційний, операційний, інформаційний та регуляторний компоненти. Зокрема, для підвищення мотиваційної складової професійної компетентності майбутніх офіцерів-прикордонників ми звертали увагу на вироблення єдиної структури цілей навчальної діяльності. Для цього викладачі намагалися систематично формулювати цілі навчання, спрямовували діяльність курсантів на їх досягнення, насамперед звертали увагу на мотивацію на кожному етапі навчання, виокремлюючи вступну, поточну i заключну мотивацію. Так, наприклад, вступну мотивацію викладачі здійснювали у формі бесіди, показу, демонстрації того чи іншого предмета або явища військовоспеціальної сфери. Поточна мотивація допомагала налагодити оптимальне педагогічне спілкування в процесі навчання, сприяла формуванню стійкого 
інтересу до навчальної діяльності та підтримувала цей інтерес на всіх етапах навчання. Цю мотивацію викладачі використовували для підтримки постійного інтересу до навчальної діяльності під час бесід, лекцій, розповідей та виконання практичних завдань.

Висновки. Впровадження методичної системи формування професійної компетентності майбутніх офіцерів-прикордонників у процесі навчання військово-спеціальних забезпечило виведення з рівноваги замкнутої та інертної системи освітнього процесу вищого навчального закладу прикордонного відомства, що було необхідним для покращення якості підготовки офіцерівприкордонників, забезпечення взаємної відповідальності суб'єктів освітнього процесу за кінцеві результати їхнього навчання.

Перспективами подалыших наукових розвідок $є$ аналіз результатів впровадження методичної системи формування у майбутніх офіцерівприкордонників професійної компетентності у процесі навчання військовоспеціальних дисциплін.

\section{ЛIТЕРАТУРА}

1. Діденко О. В. Теоретико-методичні засади формування здатності до професійної творчості в майбугніх офіцерів Державної прикордонної служби України : дис. ... доктора пед. наук : 13.00 .04 / Діденко Олександр Васильович. - Луганськ, 2009. - 533 с.

2. Мул С. А. Психологія готовності офіцера-прикордонника до професійної діяльності : дис. доктора психол. наук : 19.00 .01 / Мул С. А. - Київ, 2016. - 539 с.

3. Олексієнко Б. М. Психологічне забезпечення військової служби у прикордонних військах України / Б. М. Олексієнко // Практична психологія та соціальна робота. - 1998. - № 9 -C. 31-33.

4. Осьодло В. І. Вплив смисложиттевих феноменів на професійну діяльність офіцера / В. I. Осьодло // Вісник Національної академії оборони України : зб. наук. праць / редактор Стасюк В. В. - 2009. - № 5 (13). - С. 156-163.

5. Ставицький О. М. Теоретичні та методичні засади професійного виховання майбутніх офіцерів-прикордонників : дис.. ... доктора пед. наук : 13.00.04 / Ставицький Олег Миколайович. - Старобільськ, 2015.- 39 с.

6. Стасюк Є. В. Організаційно-психологічні особливості професійної діяльності офіцерів-прикордонників органів охорони державного кордону : дис. ... канд. психол. наук : 19.00.09 / Стасюк Євген Вікторович. - Хмельницький, 2008. - 211 с.

7. Темко Г. Д. Система виховання воїна в Збройних силах України: Структура та механізм функціонування / Г. Д. Темко, О. В. Тімченко. - Київ, 1997. - 186 с.

\section{REFERENCES}

1. Didenko O. V. (2009). Teoretyko-metodychni zasady formuvannia zdatnosti do profesiinoi tvorchosti v maibutnikh ofitseriv Derzhavnoi prykordonnoi sluzhby Ukrainy [Theoretical and methodical principles of formation of the ability to professional creativity in future officers of the State Border Guard Service of Ukraine]. Luhansk. 533. (in Ukrainian).

2. Mul S. A. (2016) Psykholohiia hotovnosti ofitsera-prykordonnyka do profesiinoi diialnosti [The psychology of the officer-border guard's readiness for professional activity]. Kyiv. 539. (in Ukrainian).

3. Oleksiienko B. M. (1998). Psykholohichne zabezpechennia viiskovoi sluzhby u prykordonnykh viiskakh Ukrainy [Psychological support of military service in the border troops of Ukraine]. Praktychna psykholohiia ta sotsialna robota. № 9. 31-33. (in Ukrainian). 
4. Osodlo V. I. (2009). Vplyv smyslozhyttievykh fenomeniv na profesiinu diialnist ofitsera [Influence of semantic life phenomena on the professional activity of an officer]. Visnyk Natsionalnoi akademii oborony Ukrainy. № 5 (13). 156-163. (in Ukrainian).

5. Stavytskyi O. M. (2015). Teoretychni ta metodychni zasady profesiinoho vykhovannia maibutnikh ofitseriv-prykordonnykiv [Theoretical and methodical principles of professional education of future officers-border guards]. Starobilsk. 39. (in Ukrainian).

6. Stasiuk Ye. V. (2008). Orhanizatsiino-psykholohichni osoblyvosti profesiinoi diialnosti ofitseriv-prykordonnykiv orhaniv okhorony derzhavnoho kordonu [Organizational-psychological peculiarities of professional activity of officers-border guards of state border guard institutions]. Khmelnytskyi. 211. (in Ukrainian).

7. Temko H. D. (1997). Systema vykhovannia voina v Zbroinykh sylakh Ukrainy: Struktura ta mekhanizm funktsionuvannia [System of education of a warrior in the Armed Forces of Ukraine: Structure and mechanism of functioning]. Kyiv. 186. (in Ukrainian).

\section{PЕЗЮМЕ}

Сергей Билявец,

кандидат педагогических наук

Национальная академия Государственной пограничной службы Украины им. Богдана Хмельницкого

\section{Экспериментальное исследование результативности методической системы формирования профессиональной компетентности будущих офицеров-пограничников в процессе обучения военно-специальных дисциплин.}

В статье охарактеризованы основные шаги по формированию профессиональной компетентности будущих офищеров-пограничников в прочессе обучения военно-специальным дисциплинам. Использование методической системь в экспериментальной работе предусматривало выведение из равновесия замкнутой системы образовательного прочесса высшего учебного заведения Госпогранслужбы путем воздействия на все ее подсистемы. Автор раскрывает основные мероприятия в подсистеме иелей и задач, в частности по определению челей обучения офичера-пограничника на основе деятельностного подхода, модели выпускника вуза и результатов формирования профессиональной компетентности будущих офищеров-пограничников. В подсистеме методов обучения военно-специальным дисциплінам был использован комплекс методов обучения, в частности методов обучения, ориентированных на преподавателя, и интерактивные методы обучения, ориентированные на курсанта и преподавателя. Освещены также меры, касаюшиеся подсистемы результатов формирования профессиональной компетентности будущих офищеров-пограничников, подсистемы деятельности научно-педагогического состава вуза, подсистемы содержания обучения военно-специальным дисциплінам и подсистемы деятельности курсанта.

Ключевые слова: офицер-пограничник; профессиональная компетентность; методическая система; подсистема целей и задач; методы обучения; военно-специальные дисциплины.

\section{SUMMARY}

Sergej Biliavets,

Candidate of Pedagogic Sciences

National academy State frontier service of Ukraine the name of Bogdan Khmelnytskij 


\section{Experimental study of the effectiveness of the methodical system of forming the professional competence to future border guard officers in the process of training in military special disciplines.}

Introduction. The border guard officer must be a specialist in various activities, possess a dynamic set of knowledge, practical skills, ways of thinking, professional, worldview and civic qualities, moral and ethical values, and also to be able to successfully carry out professional duties, that is to have a high level of professional competence. However, the traditional system of professional training of future officers in higher educational establishments does not always provide the expected result.

Purpose. Coverage of the course of experimental research on the verification of the effectiveness of the methodical system for the formation of professional competence to future border guard officers in the process of training in military and special disciplines.

Methods. The pedagogical experiment was organized in accordance with the objectives of the study. When organizing the experimental work, the composition of the experiment participants was determined, they were acquainted with the tasks of the experiment. 236 cadets of Bohdan Khmelnytskyi National Academy of the State Border Guard Service of Ukraine as well as 44 representatives of the scientific and pedagogical staff participated in various types of the research. The formative stage of the pedagogical experiment lasted from September 2013 to May 2017. It was organized on the basis of four faculties of the academy.

Results. The introduction of a methodical system for the formation of professional competence to future border guard officers in the process of military and special training ensured the removal of the equilibrium of a closed and inert system of educational process in the higher educational establishment of the border agency, which was necessary for improving the quality of training of border guard officers, ensuring mutual responsibility of the subjects of educational process for the final results of their training.

Originality. The methodical system of the professional competence formation to future border guard officers in the process of training in military and special disciplines has been developed and substantiated.

Conclusion. Prospects for further scientific research are the analysis of the results of the introduction of a methodical system for the professional competence formation to future border guard officers in the process of training in military and special disciplines.

Key words: border guard officer; professional competence; methodical system; subsystem of goals and tasks; teaching methods; military and special disciplines; cadets. 